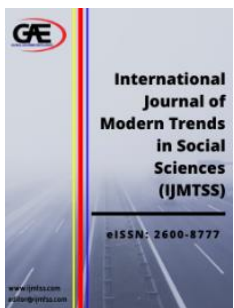

\author{
INTERNATIONAL JOURNAL OF \\ MODERN TRENDS IN \\ SOCIAL SCIENCES \\ (IJMTSS) \\ www.ijmtss.com
}

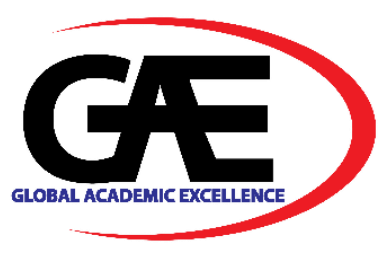

\title{
THE FACTORS THAT INFLUENCE THE CHOICE OF GROUP WORK'S SOCIAL WORK METHODS OF THERAPEUTIC COMMUNITY AND NARCOTIC ANONYMOUS MODEL IN THE SOCIAL REHABILITATION CENTER FOR DRUG ADDICTION
}

\author{
Fajar Utama Ritonga ${ }^{1 *}$, Adil Arifin ${ }^{2}$ \\ 1 Social Welfare Program Study, Faculty of Social and Political Sciences, Universitas Sumatera Utara, \\ Medan. Indonesia \\ Email: fajar.utama@usu.ac.id \\ 2 Political Sciences Department, Faculty of Social and Political Sciences, Universitas Sumatera Utara, \\ Medan. Indonesia \\ Email: rifin83@yahoo.com \\ * Corresponding Author
}

\section{Article Info:}

Article history:

Received date: 21.02 .2021

Revised date: 07.03.2021

Accepted date: 28.03 .2021

Published date: 31.03 .2021

\section{To cite this document:}

Ritonga, F. U., \& Arifin, A. (2021The Factor That Influence the Choice of Group Work's Social Work Methods of Therapeutic Community and Narcotic Anonymous Model in The Social Rehabilitation Center for Drug Addiction. International Journal of Modern Trends in Social Sciences, 4 (15), 121-132.

DOI:10.35631/IJMTSS.4150011

This work is licensed under $\underline{\text { C C BY } 4.0}$

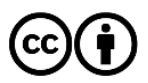

\begin{abstract}
:
This research aims to determine the factors that influence the choice of group work's social work methods of therapeutic community (TC) and narcotics anonymous (NA) model in the social rehabilitation center for drug addiction $i$. The research method is a descriptive qualitative approach, the key informants are the owners of the orphanage or program managers as well as the policymakers in the social rehabilitation center for drug addiction. The main informants are social workers and counselors and staff in the social rehabilitation center. The data collection technique uses in-depth interviews and focuses on group discussions. The data analysis technique uses component analysis. Research locations is in Medan Community Partners Foundation (YAMIMAS Medan), Caritas Shelter House PSE in Medan City, Loka BNN (National Narcotic Agency) in Kabupaten Deliserdang, Permadi PutraSocial Institution 'INSYAF' in Kabupaten Deliserdang, Nazar Foundation in Medan. The research results are; the internal factors: for the private institution's influence by the self-desire or by joint decisions are based on careful consideration of the managers or administrators of social rehabilitation institution. For the government-owned orphanages, the choice of therapeutic community model decides by the ministry of social affairs and the national narcotics agency. The external factors: for the private institution's influence by the pieces of information from national and international seminars, or experiences in dealing with drug clients/resident, social workers, and counselors who are struggling to use therapeutic community and narcotic anonymous group work model and sharing of experiences from administrators
\end{abstract}




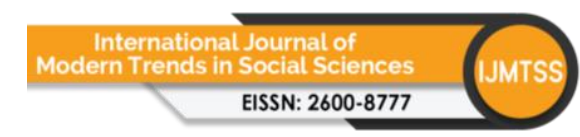

Volume 4 Issue 15 (March 2021) PP. 121-132

DOI 10.35631/IJMTSS.4150011

or manager of other social rehabilitation institution. Meanwhile, institutions under the ownership of the government are not influenced by external factors because they only carry out an order from the ministry of social affairs or national narcotics agency.

Keywords:

Factor, Choice, Therapeutic Community (TC), and Narcotic Anonymous (NA) Models

\section{Introduction}

\section{Background of the Study}

The drug problems in Indonesia are still urgent and complex. In the past decade, this problem has become rampant. This is evidenced by the significant increase in the number of drug abusers or addicts, along with the increased disclosure of drug crime cases with more diverse patterns and a more massive network of syndicates. The impact of drug abuse does not only threaten the survival and future of the abuser but also the future of the nation and state, regardless of social, economic, age, or educational level. Until now, the level of drug trafficking has penetrated at various levels, not only in urban areas but also in rural communities. (Amanda, 2017)

The National Narcotics Agency (BNN), reported the number of suspects in narcotics cases based on age groups in 2015, namely school-age children and adolescents under 19 years amounted to 2,186 cases or 4.4 percent of the total suspects. Furthermore, the BNN addressed a report in September 2016 there were around 4.2 million drug users in Indonesia. About 70 percent of users are workers, 22 percent of students and university students and 8 percent are unemployed. This drug abuse if we observe like an iceberg phenomenon, which appears on the surface only a little, but in fact, the number of cases is much larger. (Hikmat, 2020)

In 2017, the National Narcotics Agency (BNN) has revealed 46,537 drug cases throughout Indonesia, this is a form of the seriousness of the National Narcotics Agency (BNN) in fighting Drug Abuse in Indonesia. Throughout 2017, the National Narcotics Agency (BNN) confiscated hundreds of tons of drugs including 4.71 tons of shabu-shabu (methamphetamine), 151.22 tons of marijuana, 2,940,748 ecstasy pills, and $627.84 \mathrm{~kg}$ of liquid ecstasy. (Andhitia, 2017) in (Ritonga 2020)

Cases of abuse of Psychotropic Narcotics and Addictive Substances (Drugs) in Indonesia from year to year also continued to increase where in 2008 there were 3.3 million $(3,362,527)$ with a prevalence of $1.99 \%$ to 4 million in $2011(4,071,016)$ with a prevalence of $2.32 \%$ and it is predicted that this figure will continue to increase in 2015 to 5.1 million $(5,126,913)$ with a prevalence of $2.8 \%$. It is known that $5.3 \%$ of them are students. (Sholihah, 2013) in (Ritonga 2020)

This condition is considered to be increasingly damaging to the morale of students and the young generation if it is not anticipated immediately. Drug trafficking is not only found in schools and campuses but has also spread to rural areas that are difficult to monitor by the police. Previously, the National Narcotics Agency (BNN) pocketed the prevalence rate of Drug 


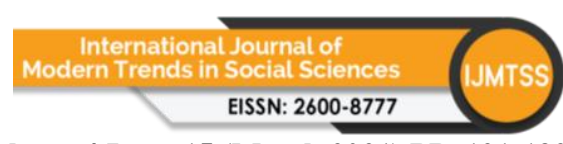

Volume 4 Issue 15 (March 2021) PP. 121-132 DOI 10.35631/IJMTSS.4150011

Abuse in 2015, reaching 2.2 percent or around four million people in Indonesia who are caught in drug circles. The drugs are capable of claiming 40 to 50 lives of the younger generation in a day. State losses due to drug abuse are not small. The survey was conducted by the National Narcotics Agency (BNN) and the University of Indonesia Health Research Center in 2014 that the country experienced a loss of 63.1 trillion rupiah due to drug abuse. (Aminah, 2018) in (Ritonga. 2020)

According to the National Narcotics Agency (Juandi, 2017) In (Ritonga 2020) recorded that there are 350 thousand people who are users and affected by drugs in North Sumatra. The number of users and affected by drugs is spread across 33 kecamatan/districts in North Sumatra City. (Ritonga, 2020)

Still in (Juandi, 2017) In (Ritonga 2020) The National Narcotics Agency (BNN) estimates that there are around 10 thousand people who use drugs in every district in North Sumatra City. The condition that is more concerning North Sumatra is no longer just a drug marketing location but a producer and distribution location to other areas. Residents affected by drugs are almost evenly from the age of 10 to 59 years. Currently, there are 8 models in the handling of victims of Narcotics, Psychotropic and Addictive Abuse that are developed in drug rehabilitation centers, as well as other institutions that serve drug addiction such as Dependency Hospitals Medicine (RSKO), Islamic Boarding School, Halfway House, Reporting Mandatory User Institute (IPWL). The service models are 1). Therapeutic Community, 2). Medical Model, 3). Minnoseta Model, 4) Electric Model, 5) Multi-Discipline Model, 6) Traditional Model, 7) Faith-Based Model, 8) Community-based Drug Management Model. (Ritonga, 2020)

\section{Problem Statement}

The two most widely applied models in drug addiction services (Gani, 2013) in (Ritonga 2020) are the Therapeutic Community Model and the Narcotic Anonymous Model. Almost every drug addiction service agency in North Sumatra uses these two models or a combination of these two models. Therapeutic Community (TC), is a treatment that uses a psychosocial approach, where together with other former drug users they live in one environment and help each other to achieve healing. The process of change expected from the Therapeutic Community (TC) is a change in behavior, emotional development, intellectual development, spiritual development, and work skills as well as providing attention, protection, and supporting the balanced physical, mental, and spiritual development, with love and mutual feeling, respect for each individual and the community as a whole, to create harmony in the environment. (Ritonga, 2020) Another method that is often used is the Narcotics Anonymous Model. (Halgin \& Whitbourne, 2009) in (Ritonga, 2020)

There is no better model between the Therapeutic Community (TC) Model and the Narcotic Anonymous (NA) Model at the Drug Social Rehabilitation Center because these two models are the most popularly used of the 10 existing models in handling drug abuse. The Therapeutic Community (TC) Model and the Narcotic Anonymous (NA) Model at the Drug Social Rehabilitation Center are equally good because they aim to restore the resident's social function and prepare the resident to return to his family and community. The combination of the Therapeutic Community (TC) Model and the Narcotic Anonymous (NA) Model at the Drug Social Rehabilitation Center is the choice of the manager of the Drug Social Rehabilitation Center managed by the private / community / NGO because they think it will produce even 
better results if it combines the Therapeutic Community (TC) Model and Narcotic's Anonymous (NA) Model at the Drug Social Rehabilitation Center. The selection of the Therapeutic Community (TC) Model and the Narcotics Anonymous (NA) Model at the Drug Social Rehabilitation Center is the choice for administrators of the Drug Social Rehabilitation Center. (Ritonga, 2020)

\section{Research Objectives}

The objectives of the study are to analyze the factors that determine drug social rehabilitation homes using the social work group work method of Therapeutic Community and Narcotic's Anonymous (NA) models in drug rehabilitation homes established by the community, NonGovernment Organizations (NGO) or known as the Mandatory Reporting Institution (IPWL).

\section{Significance of the Study}

This research is expected to be useful to students of Social Worker, Counselor, manager program drug social rehabilitation homes using the social work group work method of Therapeutic Community and Narcotic's Anonymous (NA) models.

\section{Literature Review}

One well-known method of rehabilitation is the therapeutic community (abbreviated as TC). It was first coined by James Moreno (1934), who was called the "Father of Psychodrama" and implemented by Maxwell Jones (1952) for people with psychiatric disorders. The therapeutic community program is carried out in a rehabilitation process for those who experience drug dependence, implemented for the first time in America for addicts (injection needle users), as a result of the failure of therapy that has been provided by a hospital. Furthermore, this method has spread and become one of the methods used in world rehabilitation program services, including in Indonesia. In the attachment of Permenkes (health minister regulation) no. 996 / MENKES / SK / VII / 2012, it is explained that psychosocial services can be carried out with a non-medical approach, for example with the therapeutic community method. (Said, 2019).

The TC method uses 4 structures and 5 pillars which form the basis for implementing social rehabilitation. The social rehabilitation curriculum, from material to learning methods, is based on these 4 structures and 5 pillars. The four structures are the values instilled in the client, while the five pillars are the way to instill these values. Each client is required to memorize and then practice these 4 structures and 5 pillars as part of their daily life. To make it easier for clients to memorize, clients are required to write everything down in a walking paper which they will always carry with them while they are still in the initial phase of rehabilitation (known as the induction phase). One of the walking papers contains the values that must be applied by clients during social rehabilitation using the TC model. These values include honesty, responsibility, trust in the environment, equal reciprocity, and forgiveness. In carrying out daily tasks and during all therapy sessions, clients are required to live these values. (Ardani and Cahyani, 2019)

Handling with a spiritual approach such as Alcoholics Anonymous (AA) 12 Step recovery communities and Narcotics Anonymous or commonly abbreviated as NA. (Halgin \& Whitbourne, 2009).

The recovery process using the 12-Steps of NA approach, in general, includes the process of self-acknowledgment that there is a problem with addiction that is being experienced, seeking 


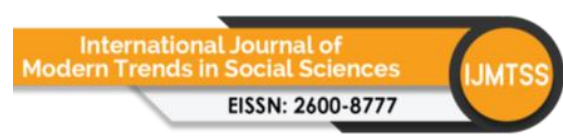

Volume 4 Issue 15 (March 2021) PP. 121-132

DOI 10.35631/IJMTSS.4150011

help from outside oneself, namely from the community, engaging in a thorough self-inventory process to see the mistakes that have been made by oneself, disclosing oneself to fellow community members about secrets and feelings, making atonement for mistakes that have been committed to people who have been hurt, and helping fellow addicts to provide support for the recovery of themselves and others. (Halgin \& Whitbourne, 2009).

The core of the NA program is the application of spiritual principles in everyday life (Halgin $\&$ Whitbourne, 2009).NA is a nonprofit fellowship or society of men and women for whom drugs had become a major problem. We are recovering addicts who meet regularly to help each other stay clean. This is a program of complete abstinence from all drugs. There is only one requirement for membership, the desire to stop using. We suggest that you keep an open mind and give yourself a break. Our program is a set of principles written so simply that we can follow them in our daily lives. The most important thing about them is that they work. (Narcotics Anonymous World Services, 2016)

There are no strings attached to NA. We are not affiliated with any other organizations. We have no initiation fees or dues, no pledges to sign, no promises to make to anyone. We are not connected with any political, religious, or law enforcement groups, and are under no surveillance at any time. Anyone may join us, regardless of age, race, sexual identity, creed, religion, or lack of religion. We are not interested in what or how much you used or who your connections were, what you have done in the past, how much or how little you have, but only in what you want to do about your problem and how we can help. The newcomer is the most important person at any meeting because we can only keep what we have by giving it away. We have learned from our group experience that those who keep coming to our meetings regularly stay clean. (Narcotics Anonymous World Services, 2016)

Jordan L. Mariano in 2019 with title The Impact Of Therapeutic Community In The Perception Of A Probationer In Quirino Province, Philippines. The result showed that the impact of the therapeutic community in the perception of probationers improved their social skills. Behavioral change, positive outlook, spiritual growth, livelihood programs led to employable technical skills. It is recommended that the probation office may materials during training and for capital in the livelihood program. Future work may be added to introduce new knowledge on the therapeutic community for the probationer.

Research conducted by Fajar Utama Ritonga (2019) with the title Comparison of Therapeutic Community (TC) and Narcotics Anonymous (NA) Models in Drug Addiction Social Welfare Services from the 7 stages of the participation model used there are differences in the Functional Participation stage using the Therapeutic Community (TC) Model. 55.5 "\%, while the Narcotic Anonymous (NA) Model is $100 \%$, at this stage the difference is very significant at $44.5 \%$, and interactive participation using the Therapeutic Community (TC) Model is $65.4 " \%$, while the Narcotic Anonymous Model ( NA) is 44\%, at this stage there is a difference of $21.5 \%$. (Ritonga, 2019)

Research conducted by Irfan Ardani and Heti Sri Hari Cahyani in 2019 with the title Effectiveness of the Therapeutic Community Method in Preventing Drug Abuse Relapse in Pamardi Putra Galih Pakuan Social Home, Bogor 2017. The results of this study indicate that the dropout rate of social rehabilitation at PSPP Galih Pakuan reached $44.8 \%$ in 2017, while 


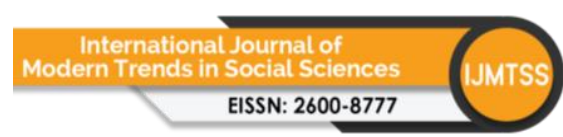

Volume 4 Issue 15 (March 2021) PP. 121-132

DOI 10.35631/IJMTSS.4150011

the relapse rate is estimated at $30 \%$ of clients who passed rehabilitation. On the other hand, various studies have stated that the TC method is a relatively more effective method than other social rehabilitation methods in reducing drug use and anti-social behavior due to drug use. The challenge with the TC method is that the dropout rate is quite high. Compared to other social rehabilitation methods, TC is effective in improving the social functioning of drug users through strengthening individuals by fostering self-confidence, emotional and spiritual management. (Ardani and Cahyani, 2019)

Research conducted by Trilia and Eva Rusmini in 2019 with the title The Factors Of Using Drug Abuse Related To The Recurrence Of Patients At Mental Hospital In Province South Sumatra. The result From the result of this study showed that the highest proportion of NAPZA users patients at RS. Ernaldi Bahar in South Sumatra was age 25-44 adult 57.6\%, high school middle education level $48.5 \%$, entrepreneur $51.5 \%$, introvert personalities $57.6 \%$, unhealthy environment $54.5 \%$, harmonic family $54.5 \%$ same age friends with drug addiction $51,5 \%$ and recurrence $60,6 \%$. The result of the statistical test showed 2 variables that related to recurrence were environmental factors (0.004) $\alpha$ and same-age friends with drugs $\alpha 0.008$, whereas the other 2 variables $\alpha 0.172$. Conclusion: It is hoped that health officials at the hospital can strengthen their programs in the rehabilitation center, which can support all patients to elevate the motivation of NAPZA abuse users so they can survive without using drugs anymore.

Research by Restrepo, C.G., etc (2018) Title: Therapeutic Communities In Latin America: An International Descriptive Study In Different Countries Across Latin America. Result Of the 285 TCs identified in the 5 countries, 176 (62\%) accepted to participate in this study. The TCs quality was evaluated according to the scoring system established by De Leon, finding that $70 \%$ of the facilities have scores of $11 / 12$ or $12 / 12$ using these criteria. We also found that the majority of the De Leon criteria are known by more than $90 \%$ of the institutions, however, the dimensions of "separation of the community" and "encounter groups between residents" were the least known with 63 and 85\% respectively. The main reasons for the abandonment of TCs were "not accepting the rules of the institution", "lack of money" and "not feeling comfortable with the facilities". 98\% of the TCs provided services to other substance abuse problems, 94\% for alcohol, and $40 \%$ for other types of substances. Conclusions: The majority of the TCs identified in our sample meet the quality criteria established by De Leon, mostly providing services for substance abuse. However, they should put in place additional policies to improve the unfulfilled conditions and investigate the reasons for the dissatisfaction and abandonment of these institutions.

Research conducted by Era Fajriah, Husaini, and Adenan in 2016 with the title Narcotics Anonymous Method Approach in Recovery of Drug Abuse Victims at the Harapan Banua Banjarmasin Foundation. The results showed that there were 11 stages of recovery in the Narcotics Anonymous method including the 12-step principle. The material provided is emphasized on the behavior and behavior of drug abusers. 35\% development of abuser recovery. Supporting factors for recovery are motivation from the foundation, a sense of kinship, and affection. The inhibiting factor for recovery is the lack of the previous family and social support. So, it is concluded that the Narcotics Anonymous method emphasizes a sense of kinship and a feeling of co-existence. The level of victim participation who follows this method is quite high. This method has strong support for the recovery of victims of drug abuse 
and helps to improve relationships with families and regain confidence in families and themselves. (Fajriah, et al. 2016).

Based on previous research that researchers have described, the novelty of this study is to analyze the factors that influence the choice of using the Group Work Model Therapeutic Community (TC) method and the Narcotic Anonymous (NA) Model in drug rehabilitation institutions.

The simple reason for this novelty is that every year Indonesia experiences an increase in drug abuse cases, and after the victims are treated or restored in drug addiction institutions using these 2 popular models, they do not show significant results. Apart from other factors that cause many patients to relapse after discharge or are declared cured of drug rehabilitation institutions. The use of the Therapeutic Community (TC) model choice and the Narcotic Anonymous model by drug addiction agencies should also be an interesting thing to be a research study material.

\section{Methodology}

\section{Research Design}

According to Neuman (2005, p. 35) "descriptive research presents a picture specific details of the situation, social setting or relationship" (descriptive research aims to provide a detailed description of a social situation, social relationship or social setting). By using this type of research, it is expected to be able to describe and analyze the factors of choosing the Therapeutic Community (TC) and Narcotics Anonymous (NA) group work model social work method in drug addiction social rehabilitation homes. Report Mandatory User Institution (IPWL).

\section{Research Location}

This research was carried out at the Drug Addiction Social Rehabilitation Center using the Therapeutic Community (TC) model and the Narcotic Anonymous (NA) model, namely (IPWL Nazar in Medan City, Medan City's YAMIMAS Community Partners Foundation, the Caritas PSE Halfway House Medan City, Panti Perpadi Putra " INSYAF "Deliserdang Regency, LOKA BNN Deliserdang Regency.

\section{Research Informant}

The research informants used in this study used a purposive technique (aiming) which consisted of the following: Key informants, namely the owner of the orphanage or drug addiction social rehabilitation program manager who knew about the selection of the group work model method of Therapeutic Community (TC) and Narcotic Anonymous (NA) in drug addiction social rehabilitation center. The main informants are Social Workers and Counselors and Staff who are involved and knowledgeable about the Therapeutic Community (TC) and Narcotics Anonymous (NA) at drug addiction social rehabilitation centers. The technique of collecting data was done by in-depth interview, data analysis technique. The technique of data analysis used a comparative analysis technique, namely using a contrasting approach between elements. 


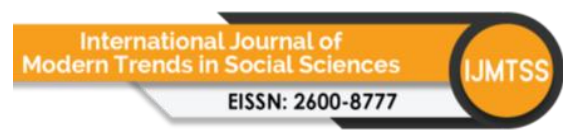

Volume 4 Issue 15 (March 2021) PP. 121-132

DOI 10.35631/IJMTSS.4150011

\section{Instrument and Measurement}

The data was collected using literature studies, field observations, in-depth interviews and focus group discussions, using interview guides that have been prepared and adapted to field conditions.

Data analysis techniques as a whole involve interpreting data in the form of text or images. The data analysis process begins by examining all data from various data sources. The researcher makes data processing steps by making categories of the information obtained (Open Coding), selecting one of the categories by placing it in a theoretical model (axial coding), then compiling a story of the relationship between categories (selective coding). (Creswell 2012, 274).

The data analysis technique uses the Component Analysis technique, which is a contrasting approach between elements.

\section{Findings}

The choice to use one of the 10 popular models in providing services in drug social rehabilitation institutions is an independent choice for the orphanage manager, but not all institutions can make choices about using the TC and NA group work methods. Based on the results of interviews with research informants, it is known that social rehabilitation institutions that are free by themselves determine the use of the NA model and the TC model or the combined model of NA and TC are social drug rehabilitation institutions formed by the community such as the Mandatory Reporting Institution of the Nazar Foundation in Medan City which uses a combination of TC and NA, then the Caritas PSE Halfway House in Medan City also uses a combined model of TC and NA, and the Medan City Community Partners Foundation (YAMIMAS), which uses the NA model in providing social welfare services for drug addiction through social rehabilitation homes.

Based on the results of the study, it is also known that the two popular models used in drug social rehabilitation centers, both the TC model and the NA model, are both good and effective in their respective social rehabilitation institutions. This is because not all problems in the handling of residents in social rehabilitation institutions only have to use one particular model. For example, only using the NA model, which is based on research results (Ritonga, 2019) is better than the TC model in increasing resident participation and changing resident behavior.

The NA model used by YAMIMAS requires that prospective residents or drug users who will get services at the YAMIMAS Social Rehabilitation Center must be at the entry-level user level (new) and have an awareness that they have a problem with drugs and want to get away from drugs. So based on this awareness, prospective residents can get services at the YAMIMAS Social Rehabilitation Center in Medan, while at the LOKA BNN Deliserdang Social Rehabilitation Home, for example, they accept all levels (initial, medium, high) except users whose levels cannot be tolerated by their social rehabilitation services. to the Adam Malik Drug Addiction Hospital (RSKO) in Medan or Jakarta and with various problems how to enter (input) to LOKA BNN Deliserdang, such as being arrested by North Sumatra BNN officers, forced by parents or family, forced husband/wife with threats of divorce do not want to be rehabilitated, preferring to be in rehabilitation rather than going to prison. 


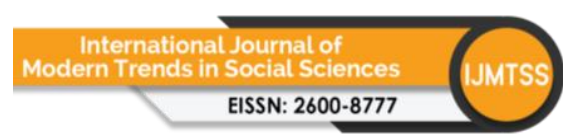

Volume 4 Issue 15 (March 2021) PP. 121-132

DOI 10.35631/IJMTSS.4150011

If you look at the input or the entry of prospective residents at the YAMIMAS Social Rehabilitation Home and LOKA BNN Deliserdang, it is clear that there are significant differences, of course, the results will be different because the input process and entry requirements are different. If the entry requirements for the prospective resident are determined, they must have a high awareness of wanting to be rehabilitated, it will be very many drug users who are not rehabilitated because most of the drug users are not aware that they are in trouble because of consuming or using drugs. And this of course will have an impact on other fields such as the increasing crime rate due to drug use, cases of domestic violence (KDRT) because the husband uses drugs or children in the family who use drugs. All of whom do not get services from the Social Rehabilitation Center.

It can be concluded that the use of the TC model at the LOKA BNN Deliserdang Regency and the "INSYAF" Putra Permadi Home is a good model because it aims to overcome drug addiction for residents, both those who come with their awareness and those who come with coercion and threats. The selection of the TC Model and the NA Model at the Drug Social Rehabilitation Institution is the most appropriate choice for the management of the social drug rehabilitation institution managed by the community / private / NGO or under the auspices of the Ministry of Social Affairs and the National Narcotics Agency (BNN).

The TC and NA models are equally good because they aim to restore the social function of the resident and prepare the resident to be well accepted when he returns to the family and the community. This is because each model has its weaknesses and strengths, as the NA model requires that prospective residents have a high level of awareness due to using drugs and have a strong desire to recover. And prospective residents are at the entry-level (or new users/trial and error) While the TC model accepts all levels of drug users (initial, middle, high), with a record that drug users at high levels after assessment, counselors or social workers can participate in social rehabilitation programs and will not disturb other fellow residents who are in the process. recovery at the drug social rehabilitation center.

Based on this, there is a drug social rehabilitation institution that uses a combined TC and NA approach, namely the Medan City Nazar Foundation Social Rehabilitation Home and the Caritas PSE Shelter in Medan City. The two orphanages used a combined approach between TC and NA because they saw the advantages and disadvantages of TC and NA, the foundation management decided to combine the TC and NA models, this was done by the Medan City Nazar Foundation, while according to the program manager of the Rumah Singgah Caritas PSE Medan City the TC model and the NA Model are equally good and need not be compared because they have the same aim to save generations of the nation from drug bondage. Of course, by using a combination of the TC and NA models, maximum results are obtained because the TC model and the NA model are equally good when combined, the maximum results will be obtained to restore the resident's social function in preparing the resident to return to his family and the community.

The factors that influence the choice of using the TC model or the NA model in this study are influenced by internal factors and external factors. The internal factor is the desire of the social rehabilitation institution manager to determine what model is most suitable for use in their social rehabilitation home using the TC, NA model, or a combination of TC and NA models. And this decision can only be made at the Social Rehabilitation Institution which is managed 


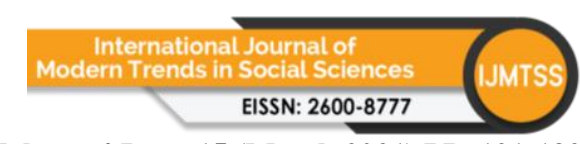

Volume 4 Issue 15 (March 2021) PP. 121-132 DOI 10.35631/IJMTSS.4150011

by the community / private / NGO, while the Social Rehabilitation Institution under the Ministry of Social Affairs and the National Narcotics Agency that manages the Social Rehabilitation Institution cannot determine the use of the TC model or the NA Model and the TC combined model. and NA in their place, because the decision to use the drug handling model has been decided by the center so that the social rehabilitation institution managers only carry out the decision under the applicable Procedural Operational Standards.

\section{Conclusion}

\section{Internal Factors}

For social rehabilitation homes owned by the community or Non-Government Organizations (NGOs) such as the Medan Community Partners Foundation (YAMIMAS) which uses the NA model, then the Medan City NAZAR Foundation and the PSE Caritas Halfway House Medan City use a combined model of TC and NA influenced by the manager's wishes or management of social rehabilitation institutions themselves, There is no intervention or compulsion to use one of the models set by other agencies or organizations, the desire to use either NA or a combination of TC and NA is a joint decision based on careful considerations.

For the orphanages under the auspices of the National Narcotics Agency (BNN), namely LOKA BNN, Deliserdang Regency, and the Putra Permadi Panti "INSYAF" in Laubakrie, Deliserdang Regency, the choice of using the TC model has been decided by the ministry or BNN so the rehabilitation center manager and addiction counselor cannot make a choice. using the TC model or the NA model in the LOKA BNN rehabilitation center in Deliserdang Regency and the "INSYAF 'rehabilitation center in Deliserdang Regency.

\section{External Factor}

Social rehabilitation homes owned by the community or Non-Government Organizations (NGOs) such as the Medan Community Partners Foundation (YAMIMAS) which uses the NA model, then the Medan City NAZAR Foundation and the PSE Caritas Halfway House Medan City based on scientific studies that have been carried out, information from national and international seminars, experiences in dealing with clients/drug residents themselves, social workers and counselors who work on the TC and NA group work model and sharing experiences from administrators or managers of other social rehabilitation institutions. While there are no factors for INSYAF and LOKA BNN institutions external because they only carry out orders from the Ministry of Social Affairs or the Central BNN.

\section{Limitations of the Study}

Because this study was conducted during the Covi-19 pandemic, the study visit time could not be longer. And some informants did not allow visits to rehabilitation centers so that interviews were conducted by telephone and FGDs were conducted through Zoom media.

\section{Suggestions for Future Research}

It is suggested that future studies research that will be carried out is the effectiveness of the role of the community on the recurrence rate of drug addicts who have recovered. 


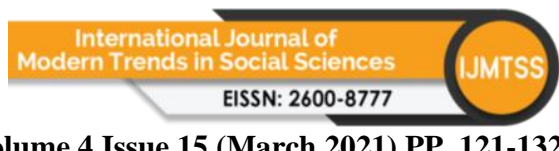

Volume 4 Issue 15 (March 2021) PP. 121-132 DOI 10.35631/IJMTSS.4150011

\section{Acknowledgments}

Researchers would like to thank the Research Institute at the Universitas Sumatera Utara for financing this research by agreement/contract Number: 273/UN5.2.3.1./PPM/SPPTALENTAUSU/2020. So that this research can be completed properly.

\section{Biodata}

Fajar Utama Ritonga is a Lecture at Social Welfare Program Study, Faculty of Social and Political Sciences, Universitas Sumatera Utara, Medan. Indonesia. Focus research interests are Social Welfare, Social Worker, Intervention Community.

Adil Arifin is a Lecture at Political Sciences Department, Faculty of Social and Political Sciences, Universitas Sumatera Utara, Medan. Indonesia. Focus Research is Decison Making, Local Politic, Political Culture. Islamic Studies.

\section{References}

Alipoor, F. Hasani, J., Moradi, A. (2015). "Effectiveness of Therapeutic Community in Executive Functions and Autobiographical Memory in People with Addiction to Stimulants". Journal: Research on Addiction Quarterly Journal of Drug Abuse. Vol. 9, No. 35, Autumn 2015 http://www.etiadpajohi.ir

Amanda, M/ P, Humaedi, S. Santoso, M.B. (2017). "Penyalahgunaan Narkoba di Kalangan Remaja ( ADOLESCENT SUNSTANCE ABUSE). Journal: Jurnal Penelitian \& PPM. Vol 4 Nomor 2. Hal. 129-389. Juli 2017 ISSN:2442-448X

Ardani, I. Dan Cahyani, H,S,H. (2019)" Efektivitas Metode Therapeutic Community Dalam Pencegahan Relapse Korban Penyalahguna Napza Di Panti Sosial Pamardi Putra Galih Pakuan Bogor Tahun 2017'. Jurnal: Buletin Penelitian Sistem Kesehatan - Vol. 22 No. 3 Juli 2019: 184-191 http://dx.doi.org/10.22435/hsr.v22i3.1281

Drugabuse.gov, (2020). "How Is Treatment Provided in a Therapeutic Community?" dapat diakses di https://www.drugabuse.gov/publications/research-reports/therapeuticcommunities/how-treatment-provided-in-therapeutic-community.

Fajriah, E., Husaini., Adenan. (2016). Pendekatan Metode Narcotics Anonymous Dalam Pemulihan Korban Penyalahgunaan Narkoba Di Yayasan Lingkaran Harapan. Jurnal: Jurnal Berkala Kesehatan, Vol. 1, No. 2, Mei 2016 : 96-105. eISSN : 2541-6472 |pISSN : 2477-3190. http://magisterkesmas.ulm.ac.id/id/2018/10/19/jurnal-berkalakesehatan-vol-1-no-2-mei-2016-96-105/

Halgin, RP \& Whitbourne S.K,. (2009).'Psikologi Abnormal: Perspektif Klinis Pada Gangguan Psikologis. Alih bahasa: Yustinus. Yogyakarta: Kanisius.

Hikmat, M.M, M. Thaha, I.L., Dwinata, I. (2020). ".The Potential Factor of Drug Abuse at Senior High School Students Accredited a in the Whole of Makassar". Joural: Hasanuddin Journal of Public Health, Volume 1 Isuse 1Hal.1-8. Februari 2020. DOI: http://dx.doi.org/10.30597/hjph.v1i1.9507

Mariano, J. L ( 2019 ) "The Impact Of Therapeutic Community In The Perception Of A Probationer In Quirino Province”. Journal: International Journal Of Scientific \& Technology Research Volume 8, Isue 10, October 2019. ISSN 2277-8616

Narcotics Anonymous World Services, (2016). NA White Booklet, Narcotics Anonymous". Booklet

Neuman, W L. (2006). Social Research Methode: Qualitative and Quantitative Approach (Sixth Editio). Needham Heights. MA: Allyn \& Bacon. 
Restrepo, C.G. etc (2018) Title: Therapeutic Communities In Latin America: An International Descriptive Study In Different Countries Across Latin America.Journal: Revista Colombiana De Psiquiattria. 2018;47(3):140-147

Ritonga, F.U. (2019). Perbandingan Model Therapeutic Community (TC) dan Narcotics Anonymous (NA) di Pelayanan Kesejahteraan Sosial Adiksi Narkoba. Jurnal: JPPUMA: Jurnal Ilmu Pemerintahan dan Sosial Politik UMA (Journal of Governance and Political Social UMA), 7 (1) (2019): 30-39. DOI: http://dx.doi.org/10.31289/jppuma.v7i1.2174

Ritonga, FU. (2020). "Model Pelayanan Kesejahteraan Sosial Adiksi Narkoba". Medan: Puspantara

Said, N.R., Maloko, T., Sanusi, N, T,. (2019) Metode Therapeutic Community bagi Residen di Balai Rehabilitasi BNN Baddoka Makassar Perspektif Hukum Islam". Jurnal: AlQadau Peradilan dan Hukum Keluarga Islam. Volume 6 Nomor 2 Desember 2019. ISSN Online: 2622-3945 ISSN Printed: 2407-8115, http://journal.uinalauddin.ac.id/index.php/al-qadau

Trilia, Rusmini, E. (2019). Faktor Penyebab Penyalahgunaan NAPZA Terhadap Kekambuhan Pasien Pengguna NAPZA di Rumah Sakit Propinsi Sumatera Selatan". Jurnal: (JPP) Jurnal Kesehatan Poltekkes Palembang. Vol. 14, No. 2, Desember 2019, eISSN 26543427 